\title{
Correction: C. Anuradha; C. Sakthivel; T. Venkatesan; N. Chellammal. Analysis of Non-Isolated Multi-Port Single Ended Primary Inductor Converter for Standalone Applications. Energies 2018, 11, 539
}

\author{
C. Anuradha ${ }^{1}\left(\mathbb{D}\right.$, C. Sakthivel $^{2, * \mathbb{D}}$, T. Venkatesan $^{3}$ and N. Chellammal ${ }^{1, *(\mathbb{D})}$ \\ 1 Department of Electrical and Electronics Engineering, SRM Institute of Science and Technology, \\ SRM Nagar 603203, India \\ 2 Department of Electrical and Electronics Engineering, JCT College of Engineering and Technology, \\ Coimbatore 641105, India \\ 3 Department of Electrical and Electronics Engineering, K. S. Rangasamy College of Technology, \\ Tiruchengode 637215, India \\ * Correspondence: tcsakthivel107@gmail.com (C.S.); chellammal.n@ktr.srmuniv.ac.in (N.C.); \\ Tel.: +91-984-056-5701 (C.S.); +91-99-6296-4643 (N.C.)
}

The authors wish to make the following corrections to their paper [1]:

In the original version of our article [1], insufficient acknowledgement was given for some of the contributions to the work. We apologize for the original error. To correct this oversight, C. Anuradha and N. Chellammal have been added as authors. The acknowledgements have been altered to more appropriately recognize the support and contributions of these two authors.

The corrected Author List, Affiliations, and Acknowledgements:

C. Anuradha ${ }^{1}$, C. Sakthivel ${ }^{2, *}$, T. Venkatesan ${ }^{3}$ and N. Chellammal ${ }^{1, *}$

${ }^{1}$ Department of Electrical and Electronics Engineering, SRM Institute of Science and Technology, SRM Nagar 603203, India; anuradha.c@ktr.srmuniv.ac.in

2 Department of Electrical and Electronics Engineering, JCT College of Engineering and Technology, Coimbatore 641105, India

${ }^{3}$ Department of Electrical and Electronics Engineering, K. S. Rangasamy College of Technology, Tiruchengode 637215, India; venketesan@ksrct.ac.in

* Correspondence: tcsakthivel107@gmail.com (C.S.); chellammal.n@ktr.srmuniv.ac.in (N.C.); Tel.: +91-984-056-5701 (C.S.); +91-99-6296-4643 (N.C.)

Acknowledgments: We thank C. Anuradha and N. Chellammal for their technical assistance, comments on the manuscript, and fruitful discussions that improved the analytical part of the paper.

\section{Reference}

1. Vel, C.S.; Venkatesan, T. Analysis of Non-Isolated Multi-Port Single Ended Primary Inductor Converter or Standalone Applications. Energies 2018, 11, 539. [CrossRef]

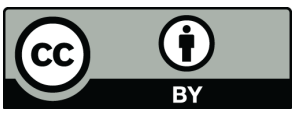

(C) 2019 by the authors. Licensee MDPI, Basel, Switzerland. This article is an open access article distributed under the terms and conditions of the Creative Commons Attribution (CC BY) license (http://creativecommons.org/licenses/by/4.0/). 